\title{
NEW COMPUTER SIMULATION PROCEDURE OF HEADING FACE MINING PROCESS WITH TRANSVERSE CUTTING HEADS FOR ROADHEADER AUTOMATION
}

\author{
NOWA PROCEDURA KOMPUTEROWEJ SYMULACJI PROCESU URABIANIA CZOLA PRZODKU \\ GLOWICAMI POPRZECZNYMI DLA POTRZEB AUTOMATYZACJI KOMBAJNU CHODNIKOWEGO
}

\begin{abstract}
The key working process carried out by roadheaders is rock mining. For this reason, the mathematical modelling of the mining process is underlying the prediction of a dynamic load on the main components of a roadheader, the prediction of power demand for rock cutting with given properties or the prediction of energy consumption of this process. The theoretical and experimental investigations conducted point out - especially in relation to the technical parameters of roadheaders used these days in underground mining and their operating conditions - that the mathematical models of the process employed to date have many limitations, and in many cases the results obtained using such models deviate largely from the reality. This is due to the fact that certain factors strongly influencing cutting process progress have not been considered at the modelling stage, or have been approached in an oversimplified fashion.

The article presents a new model of a rock cutting process using conical picks of cutting heads of boom-type roadheaders. An important novelty with respect to the models applied to date is, firstly, that the actual shape of cuts has been modelled with such shape resulting from the geometry of the currently used conical picks, and, secondly, variations in the depth of cuts in the cutting path of individual picks have been considered with such variations resulting from the picks' kinematics during the advancement of transverse cutting heads parallel to the floor surface. The work presents examples of simulation results for mining with a roadheader's transverse head equipped with 80 conical picks and compares them with the outcomes obtained using the existing model.
\end{abstract}

Keywords: roadheader, mining, cutting process modelling, computer simulation

Urabianie skał jest zasadniczym procesem roboczym realizowanym przez kombajny górnicze. Modelowanie matematyczne tego procesu stanowi dlatego podstawę predykcji obciążenia dynamicznego głównych podzespołów kombajnu, prognozowania zapotrzebowania mocy do urabiania skał o określonych własnościach oraz jego energochłonności. Prowadzone badania teoretyczne i doświadczalne wskazują, w szczególności w odniesieniu do parametrów technicznych obecnie stosowanych w górnictwie podziemnym kombajnów chodnikowych oraz warunków ich eksploatacji, że wykorzystywane dotychczas

* INSTITUTE OF MINING MECHANISATION, FACULTY OF MINING AND GEOLOGY, SILESIAN UNIVERSITY OF TECHNOLOGY, AKADEMICKA 2, 44-100 GLIWICE, POLAND 
modele matematyczne procesu urabiania mają wiele ograniczeń, a uzyskiwane $\mathrm{z}$ ich wykorzystaniem wyniki w wielu wypadkach istotnie odbiegają od rzeczywistości. Wynika to z nieuwzględnienia na etapie modelowania pewnych czynników silnie wpływających na przebieg procesu urabiania, bądź traktowanie ich w mocno uproszczony sposób.

W artykule zaprezentowano nowy model procesu urabiania skał nożami stożkowymi głowic urabiających wysięgnikowych kombajnów chodnikowych. Istotną nowością w stosunku do dotychczas stosowanych modeli jest zamodelowanie rzeczywistego kształtu skrawów wynikającego z geometrii noży stożkowych oraz uwzględnienie zmienności głębokości skrawów na drodze skrawania poszczególnych noży, wynikającej z kinematyki noży podczas przemieszczaniu poprzecznych głowic urabiających równolegle do spagu. W pracy zamieszczono przykładowe wynik symulacji urabiania głowicą poprzeczną kombajnu chodnikowego wyposażoną w 80 noży stożkowych oraz ich porównanie z wynikami uzyskanymi $\mathrm{z}$ wykorzystaniem dotychczas stosowanego modelu.

Słowa kluczowe: kombajn chodnikowy, urabiane, modelowanie procesu skrawania, symulacja komputerowa

\section{Introduction}

The key working process carried out by roadheaders is rock mining. A computer simulation of a mining process is, therefore, of fundamental importance for the identification of dynamic states of the cutting heads' drive system and for other roadheader components; for the determination of power demand; for the predication of the energy consumption of rock mining; and for forecasting the efficiency of the process. By modelling the mining process progress, a load for the picks can be determined based on an analysis of the cuts performed by particular picks, and also - load components of cutting heads, roadheader and roadheader driving systems can be determined. For this reason, works in this field have been pursued by many research institutions for years. A computer simulation of a roadheader mining process can be performed with various modelling methods. One of the research directions in this field is to use the finite elements and discrete elements method, as well as neural networks for the purpose of rock mining process modelling (Huang et al., 2013; Jaime et al., 2010; Jamie, 2011; Kui-Dong et al., 2012; Rojek et al., 2010; Shenghua, 2004; Xiang \& Duan, 2014; Xueyi et al., 2012). An alternative approach is to analyse breakout graphics. It is based on generation of the projection of cuts in a CAD environment or using a GDI interface implemented in common programming environments (Delhi, C++, etc.) (Dolipski \& Cheluszka, 1999; Hekimoglu \& Fowell, 1991; Knissel et al., 1984; Knissel \& Wiese, 1981; Tiryaki et al., 2001). Geometrical parameters of cuts made by particular picks are determined based on the projection of cuts, which sets a basis for determining a load on the picks.

A computer simulation of a roadheader mining process is a multi-step task. Cutting geometry analysis is usually a starting point. It is based on the generation of breakout graphics (cuts projection) for the defined cutting head stereometry, for the adopted roadheader operational parameters values (i.e. angular speed of cutting head, head advancement speed relative to heading face surface, the web, height of the cut layer) and for the defined properties of the cut rock (Dolipski et al., 2001).

The mathematical models describing a rock cutting process with conical picks (used widely in boom-type roadheaders) are originating from the 70's and 80's of the 20th c. - e.g. (Evans, 1984; Hurt \& Evans, 1981; Wiese, 1982). The outcomes of numerical studies carried out using them prove clearly, however, that the models lack universality, and especially lack relevance in relation to cutting the hard rocks with roadheader cutting heads. They do not reflect the actual 
character of the cutting process resulting from the geometry of the currently used picks, their position and arrangement on the cutting head side surface and their kinematics. As a result, a mathematical conical picks load model elaborated by Evans (Evans, 1984) broadly applied for determination of a conical picks load, has been continuously modified. The purpose of the modifications is to approximate the results obtained with the model to the actual values of picks load when performing a cutting process with conical picks.

The mathematical models of the rock cutting process using roadheader cutting heads used until now are reflecting the actual progress of the process only to a highly limited degree. This is due to the fact that certain factors strongly influencing the progress of the cutting process have not been considered, or they have been approached in an overly simplified manner. This is especially true for the modelling method of the shape of cuts made with conical picks, for variations in the values of cut parameters along with the movement of picks, or for variations in the values of roadheader operating parameters when advancing a cutting head along the heading face surface of the heading being drilled. Variations in operating parameters, at which the cutting process is carried out, stem from cutting head kinematics, from lateral vibrations of the boom and from driving mechanism method of its deflection (hydraulic drive). A new view is thereby required on the aspect of modelling the rock mining process progress with boom-type roadheader cutting heads.

This work is devoted to the mathematical modelling of the progress of the heading face surface cutting process with boom-type roadheader cutting heads within the scope covering primarily cutting geometry. The aim of the research pursued is to be able to represent, as closely as possible, the actual progress of the heading face surface cutting process with boom-type roadheader cutting heads. It is a significant issue, notably in the context of an effort to use effectively and efficiently such roadheaders for drilling mine heading and tunnels in hard rocks. In such conditions, such machines are influenced be especially strong vibration excitations and dynamic loading from cutting. In terms of operational durability, reliability or efficiency, it is therefore fundamental to be able to identify such phenomena in the phase of modelling studies and design works.

\section{Algorithms of the cutting process simulation procedure}

A simulation procedure of the roadheader cutting head cutting process is started by reading a file containing a set of values of parameters describing cutting head stereometry (Fig. 1). The arrangement and positioning of each of the picks on the side surface of the boom-type roadheader cutting head is characterised by five parameters - pick vertex coordinates in the cylindrical coordinate system $\left(r_{i}, l_{i}, \vartheta_{i}\right)$ and the angles of positioning its axes in the space: $\delta_{i}, \varepsilon_{i}$ (for $\left.i=1,2, \ldots, N\right)$ (Cheluszka, 2012). Data is also entered at this stage including, notably, roadheader operating parameters, i.e. (Fig. 2 and 3): the advancement of the heads towards the heading face for the slotting $y_{\max }$, the height of the cut layer $h$, deflection angles of the boom in the plane parallel and perpendicular to the floor: $\alpha_{H}$ and $\alpha_{V}$, angular speed of cutting heads $\dot{\varphi}_{G}$ and advancement speed of cutting heads $v_{o w}$, as well as values of parameters describing mechanical properties of the rocks being cut. The size of the web $z$ resulting from the current position of the cutting heads relative to the heading face surface is determined for the defined advancement of cutting heads towards the heading face and boom deflection angles. It is verified at the same time whether the defined cutting height is not larger than the maximum value corresponding to the given web. If it is so, the maximum value of the following parameter is adopted: $h=h_{\max }(z)$. 


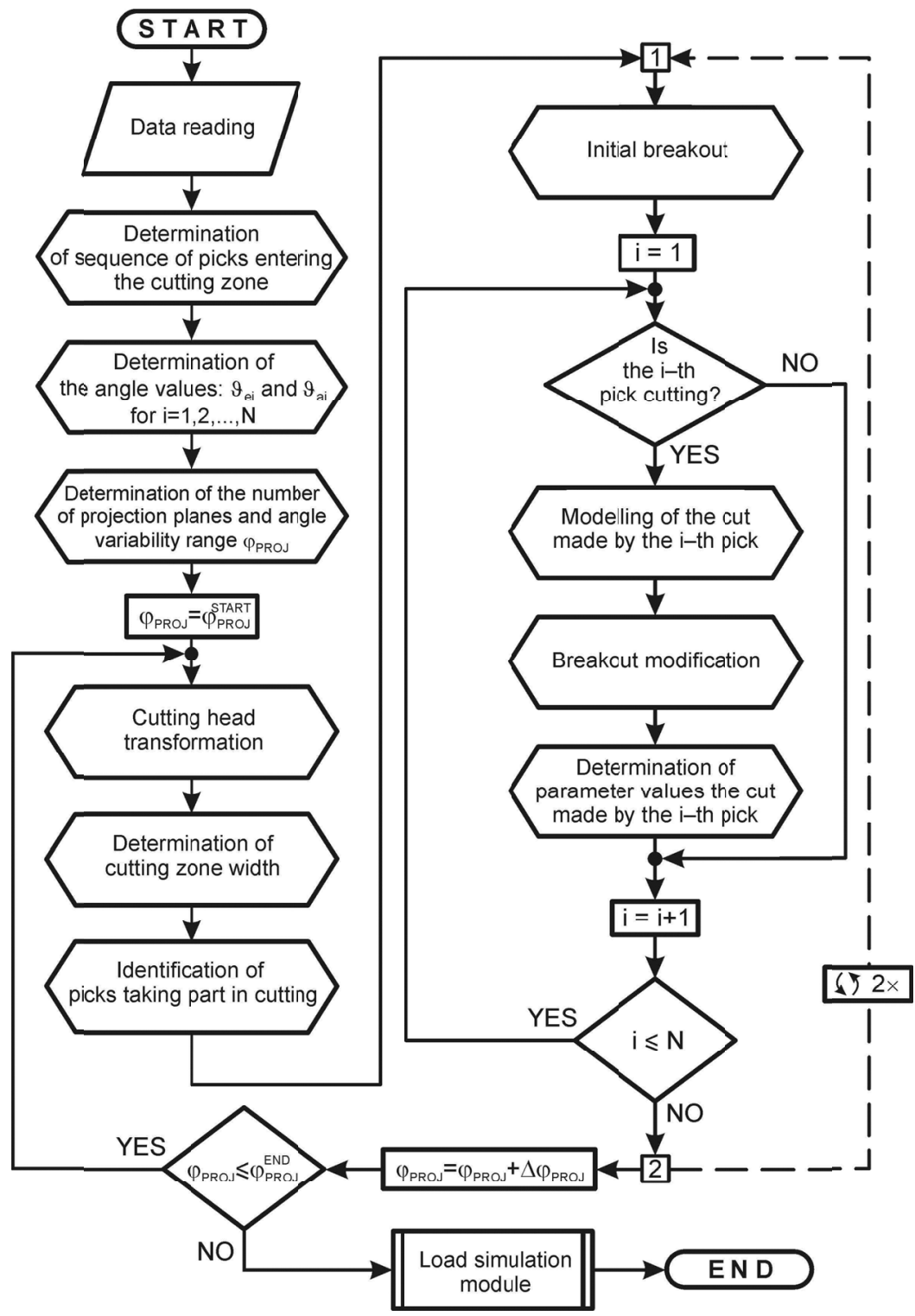

Fig. 1. Algorithm of breakout graphics generation procedure (projection of cuts) during computer simulation of cutting with cutting heads of boom-type roadheader

Once the values of the parameters characterising the cross-section size of the rock layer cut by the head are determined, the sequence of the picks entering the cutting zone (pick and rock contact zone) is determined as the cutting head is rotating. The cutting zone range of the picks taking part in cutting is then determined. It is characterised by an angle under which the $i$-th pick is entering the cutting zone $\vartheta_{e i}$ and an angle under which the pick is exiting this zone 


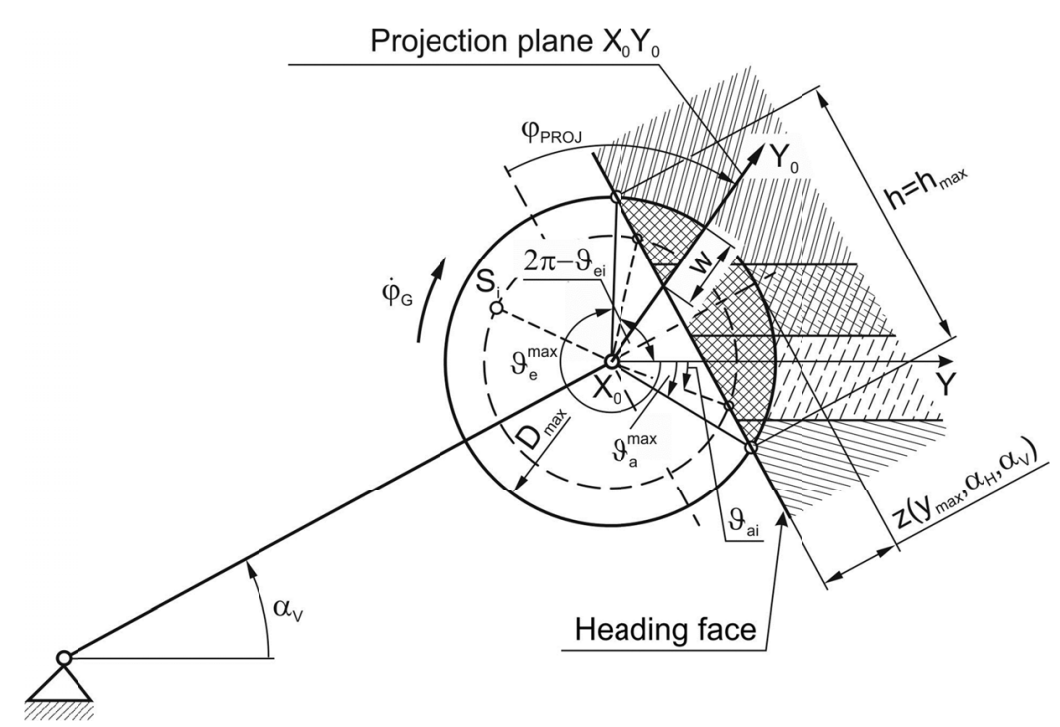

Fig. 2. Cutting zone range for $h=h_{\max }$ and width ( $w$ ) on the section corresponding to the considered projection plane

$\vartheta_{a i}$ (for $\left.i=1,2, \ldots, N\right)$. The variability range of the angle which is conditioning spatial orientation of projection planes $\varphi_{P R O J}$ and the number of planes on which the projection of cuts will be performed (Fig. 2) results from the size of cutting zones of picks arranged on the maximum diameter of the cutting head $D_{\max }$. The cuts projection planes are the section planes of the cut solid on which outlines will be represented of the section of cuts made by particular picks cutting it. A minimum value of the angle under which a pick is entering the cutting zone and a maximum value of the angle under which a pick is exiting the cutting zone is determined in order to identify the maximum size of the zone:

$$
\vartheta_{e}^{\min }=\min \left\{\vartheta_{e i}\right\} ; \quad \vartheta_{a}^{\max }=\max \left\{\vartheta_{a i}\right\}
$$

The number of projection planes considered when simulating the cutting process is calculated as the total part of the quotient of the central angle conditioning the maximum range of the cutting zone and the projection step $\Delta \varphi_{P R O J}$ :

$$
N_{\text {PROJ }}=\mathrm{E}\left[\frac{2 \pi-\vartheta_{e}^{\min }+\vartheta_{a}^{\max }}{\Delta \varphi_{\text {PROJ }}}\right]
$$

where: $E[]-$ the total part of the argument in the brackets.

Moreover, the variability range of the projection plane angle: $\varphi_{P R O J}^{S T A R T}$ and $\varphi_{P R O J}^{E N D}$ is determined according to the angle values of $\vartheta_{e}^{\min }$ and $\vartheta_{e}^{\max }$.

By changing the value of the projection plane angle $\varphi_{P R O J}$ in the range of $\varphi_{P R O J}^{S T A R T}$ to $\varphi_{P R O J}^{E N D}$ a projection is performed of cuts made by picks taking part in the cutting process in the consid- 


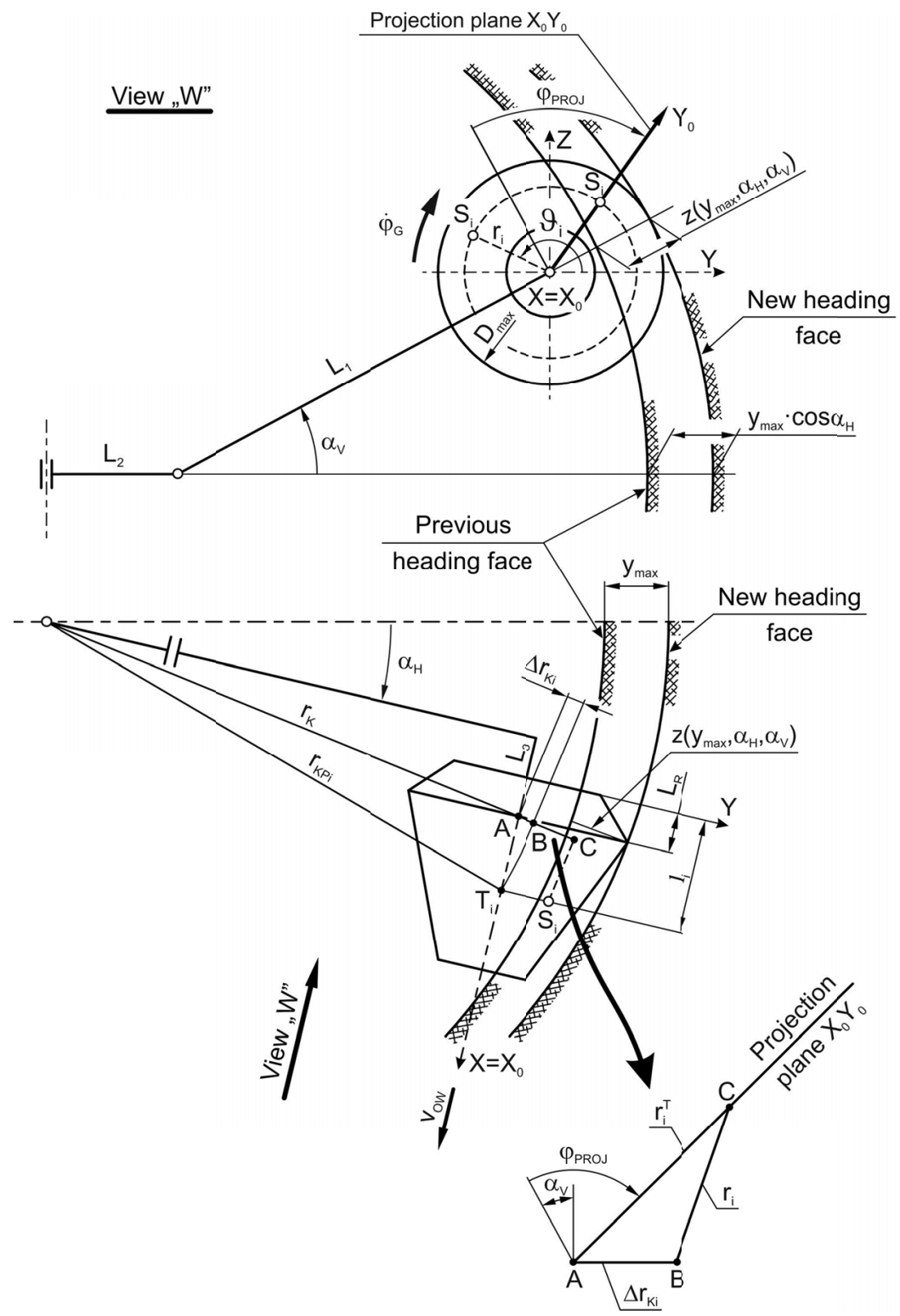

Fig. 3. Concept of shape transformation of the head picks envelop for the purpose of computer simulation of cutting process when deflecting a boom in the plane parallel to the floor (working movement)

ered projection plane. This is preceded by the transformation of coordinates of cutting head picks vertexes (the purpose and method of such transformation is described in item 3. of the paper) and by identification of the picks taking part in cutting. The number of picks taking part in the cutting process varies in particular sections of the cut solid (projection planes). This number depends on the width of the cut layer in the considered section $w$ (Fig. 2). This width results 
here from the size of the web $z$, from the maximum diameter of the cutting head $D_{\max }$ and from the angle value $\varphi_{P R O J}$ :

$$
w=0,5 \cdot D_{\max }-\frac{0,5 \cdot D_{\max }-z\left(y_{\max }, \alpha_{H}, \alpha_{V}\right)}{\sin \varphi_{\text {PROJ }}} \text {, for } \varphi_{\text {PROJ }} \neq 0 \text { and } \varphi_{P R O J} \neq \pi
$$

After identifying which picks penetrate the considered projection plane (thus taking place in cutting), an initial breakout is generated. An initial breakout is representing the shape of the projection plane penetration edge through the free surface of the rock being cut. If this shape is not known (it was not determined earlier, for example during a cutting simulation for a rotation made earlier by a cutting head), breakout graphics is generated twice (the part of the algorithm between the points: 1 and 2 ). For the first time - it assumes a simplified shape created by a broken line going through projection plane penetration points through the vertexes of individual picks. For the second time, the initial breakout is achieved as a line representing a breakout shape when the cutting head has performed the considered rotation, moved backward (towards the axis $\mathrm{Y}_{0}$ of the system of coordinates $\mathrm{X}_{0} \mathrm{Y}_{0}$ ) by head displacement during its one rotation of: $\Delta x=v_{o w} \times T_{c}$ (where: $T_{c}-$ cutting head rotation period).

While simulating the penetration of the considered projection plane through particular picks taking part in cutting, the cuts made by picks are modelled. A breakout, representing the surface shape of the cut rock after the transition of individual picks, is modified after performing each cut. Cut characterisation parameters are determined for each cut, such as: depth $g_{i}\left(\varphi_{P R O J}\right)$, field area $S_{i}\left(\varphi_{P R O J}\right)$ and cutter spacing measured on the left and right side of the cut: $t_{L i}\left(\varphi_{P R O J}\right)$ and

$t_{R i}\left(\varphi_{\text {PROJ }}\right)$. The tabulated values of such parameters form a basis for determination of a picks load curve and further - for determination of the external load components of the cutting head, cutting system and other roadheader components subject to a load from cutting in the function of cutting head rotation angle or time.

The process presented above is repeated for the next projection planes representing the next cross-sections of the cut solid, whose orientation is characterised with the angle $\varphi_{P R O J}$.

A picks load simulation is started and the curve of cutting head load components is determined once the generation of breakout graphics is completed. A load on the picks in the next rotations of the cutting heads is predicted based on the Evans model for conical picks (Evans, 1984) considering variations in the pick load connected with the character of the progress of the detachment process of rock grains distinctive for brittle materials (rocks, concrete, etc.). It was assumed based on the investigations (Dolipski \& Cheluszka, 1998) that when rocks are cut with boom-type roadheader cutting heads, a picks load curve in subsequent detachment cycles of rock grains is triangle-shaped with a gap.

\section{The modelling of cuts for the purpose of breakout graphics generation}

In the case where cutting heads are advancing parallel to the floor surface (during working movement), the picks are moving along the helixes described at the side surface of the torus. As already mentioned, the projection of cuts, based on which cut geometry is identified, is undertaken for a number of cuts sections formed due to cutting through the worked solid with projection 
planes. The planes are going through the axis of rotation of the cutting head and their orientation is determined with the angle $\varphi_{P R O J}$. An approach, consisting of analysing the geometry of cuts in subsequent sections of the cut layer, is an important new element versus the methods of cutting process simulation with roadheader cutting heads employed until now. Breakout graphics used to be generated only for one projection plane perpendicular to the heading face surface. It was assumed that the depth of cuts made by particular picks within the entire cutting zone range is constant and assumes a value as for the above-mentioned projection plane (Knissel et al., 1984; Mahnert et al., 1990; Rostami et al., 1994). Such an assumption would be correct in the case where a cutting head is advanced parallel to the surface of the cut rock with rectilinear movement. The movement is performed along the arc in fact. This is because cutting heads are advanced during rotary motion of a boom on the end of which cutting heads are rested. In case of working movement, this rotation is performed around the axis of rotation of a turntable perpendicular to the floor. Consequently, the centres of circles made by individual cutting picks during cutting head rotation around its axis of rotation are at different distance from the turntable axis of rotation (are moving along arcs with different radius). The difference in the radii results from the boom deflection angle values in the plane perpendicular to the floor and the distance of particular picks to the longitudinal axis of the boom (conditioned by the distance $L_{3}$ and the coordinate value $l_{i}$ ). Consequently, along with the movement of picks accompanying cutting head rotation, the depths of cuts are changing. This also changes the size of the field area of the cross-section of cuts and their shape.

Considering mathematical description of the motion trajectory of picks for the purpose of breakout graphics generation, it is convenient to consider the cutting process accompanying cutting head advancement along the straight line, parallel to the surface of the cut rock. In order to ensure relevance of the results obtained this way, however, for the actual progress of the cutting process when deflecting a boom in the plane parallel to the floor, it is indispensable to transform the shape of the cutting head pick tip envelope. This transformation consists of conversion of values of coordinates $r_{i}$ describing the position of cutting picks vertexes in relation to the cutting head rotation axis. A condition must be satisfied here that the depth of cuts as well as cutter spacing during cutting head advancement with a rectilinear advancing motion correspond to the values of such values when the cutting head is advanced along an arc (Dolipski \& Cheluszka, 1999). This transformation is carried out for each considered plane of projection. The representation equivalence is ensured of cuts made by particular picks when cutting the heading face surface in the form of a bowl (the actual cutting process progress) and of a model established for cutting head advancement along the straight line (cutting simulation of the flat heading face surface). The curvature radius of the heading face in a plane perpendicular to the floor depends on geometric parameters of the roadheader cutting system (mainly on the length of the boom $L_{1}$ ) - Fig. 3 . The curvature radius of the heading face in a plane perpendicular to the floor depends, however, on, both, the length of the boom $L_{1}$ and its deflection angle in the plane perpendiculas to the floor $\alpha_{V}$, the maximum diameter of the cutting head $D_{\max }$ and its position (specified with the coordinate $L_{R}$ ), as well as geometrical dimensions of the roadheader turntable (the distance between the axes of rotation $L_{2}$ ) (Sobota, 2015). Therefore, during the transformation of the shape of the picks envelopes, a family of heads is achieved differing to a certain degree with stereometry, for which breakout graphics is generated in the corresponding projection planes. This way, in each of the considered cross-section of the cut solid, the actual curvature of the heading face surface is considered and the actual curvature of the track along which individual cutting head picks are moving. 
A shift in the centres of circles $\left(\Delta r_{K i}\right)$ made by picks vertexes during cutting head rotation around its own axis of rotation caused by the displacement of cutting heads along the arc track, can be determined based on the following formula (Fig. 3):

$$
\begin{aligned}
\Delta r_{K i}=r_{K P i}-r_{K}= & \sqrt{\left(L_{1} \cdot \cos \alpha_{V}+L_{2}\right)^{2}+\left(L_{3}+l_{i}\right)^{2}}+ \\
& -\sqrt{\left(L_{1} \cdot \cos \alpha_{V}+L_{2}\right)^{2}+\left(L_{3}+L_{R}\right)^{2}}
\end{aligned}
$$

During the transformation of the shape of the picks tips envelopes $\mathrm{S}_{\mathrm{i}}($ for $i=1, \ldots, N)$, a corrected value of the distance between the vertexes of picks to the axis of rotation of the cutting head $r_{i}^{T}$ is determined. The relationships are used here existing in the ABC triangle, in which the length of one side (the base $\mathrm{AB}$ ) equals $\Delta r_{K i}$ (Fig. 3). The length of the other side (section $\mathrm{BC}$ ) corresponds to the actual distance of the considered pick vertex to the axis of rotation of the cutting head $r_{i}$. The length of the third side (section AC) is the distance searched from the axis of rotation of cutting head of the pick vertex after transformation:

$$
r_{i}^{T}= \begin{cases}\frac{\left|\Delta r_{K i}\right|+r_{i} \cdot \sin \left(\varphi_{\text {PROJ }}-\alpha_{V}-\gamma\right)}{\sin \left(\varphi_{\text {PROJ }}-\alpha_{V}\right)}, & \text { when } \varphi_{\text {PROJ }} \neq \alpha_{V} \\ r_{i}, & \text { when } \varphi_{\text {PROJ }}=\alpha_{V}\end{cases}
$$

whereas a value of the auxiliary angle $\gamma$ is determined from the following dependency:

$$
\gamma=\arcsin \left[\frac{\left|\Delta r_{K i}\right|}{r_{i}} \cdot \cos \left(\varphi_{P R O J}-\alpha_{V}\right)\right]
$$

where:

$L_{1}, L_{2}, L_{3}-$ geometrical dimensions of the roadheader boom and turntable,

$r_{i}, l_{i}-$ coordinates of the vertex of the $i$-th pick,

$L_{R}$ - the distance between the vertexes of picks arranged on a circle with the largest diameter $\left(D_{\max }\right)$ from the base of the cutting head (the plane YZ),

$N$ - the number of picks on the cutting head,

$\alpha_{V}-$ boom deflection angle in the plane perpendicular to the floor,

$\varphi_{\text {PROJ }}$ - the angle defining the positioning of the considered projection plane.

The transformation effects of the picks tips envelopes shape for an example of a roadheader cutting head are shown in Fig. 4. As the value of the angle $\varphi_{P R O J}$ determining the orientation of the considered projection plane comes closer to $90^{\circ}$, the picks vertexes envelop becomes flatter and flatter. The distance between the vertexes of the neighbouring picks after transformation are therefore smallest when the projection plane is overlapping the longitudinal axis of the boom $\left(\varphi_{\text {PROJ }}=90^{\circ}\right)$. On the other hand, when the projection plane is perpendicular to the longitudinal axis of the boom $\left(\varphi_{P R O J}=0\right.$ or $\left.180^{\circ}\right)$, then the arrangement of picks vertexes after transformation on the cutting head envelop is corresponding to their actual arrangement on the head. The difference between the actual maximum and minimum distance of picks vertexes from the axis of rotation for the considered cutting head was $275 \mathrm{~mm}\left(D_{\max }=1100 \mathrm{~mm} ; D_{\min }=550 \mathrm{~mm}\right)$. When considering the projection plane for $\varphi_{P R O J}=90^{\circ}$ - the difference has decreased to $186 \mathrm{~mm}$, i.e. nearly by one-third. 


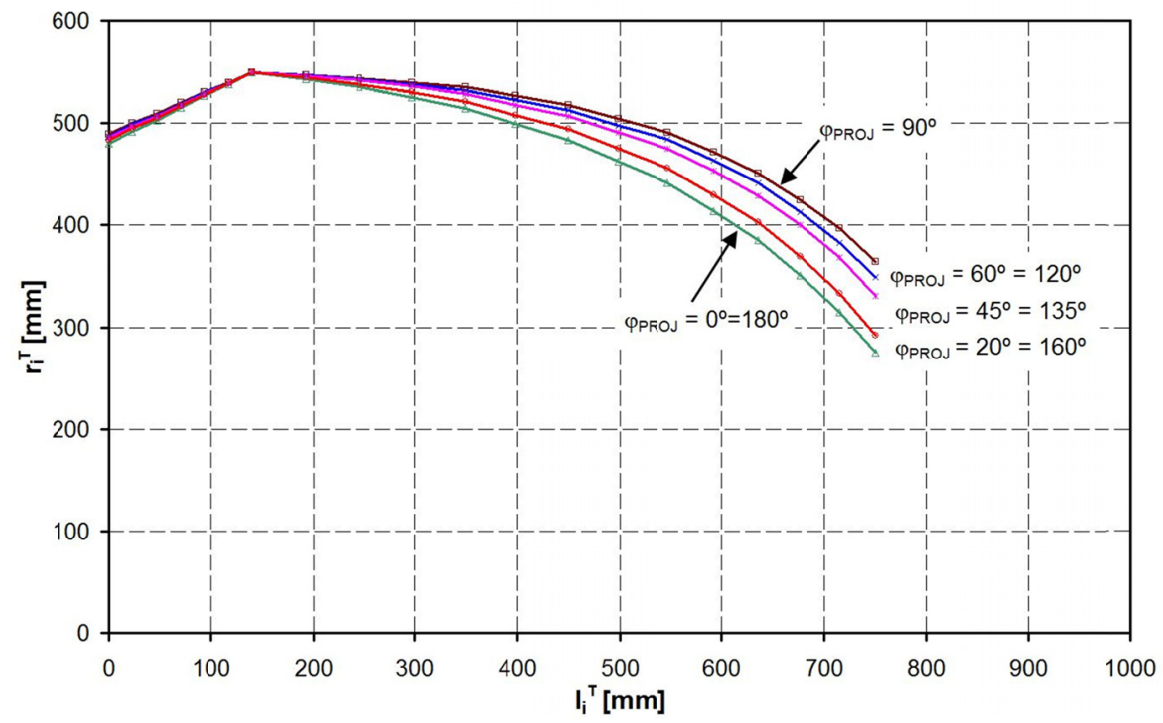

Fig. 4. Envelop shape of picks of transverse cutting head after transformation for different projection planes

Breakout graphics (projection of cuts) represents an image of section shapes and the consequences of cuts made by picks taking part in the rock cutting process in the considered projection plane. The picks are penetrating the projection plane in the sequence resulting from their arrangement on the cutting head. The aspect of breakout graphics generation hence comes down to the modelling of the shape of penetration edge of side surfaces and the bottom of cuts of the projection plane whose spatial orientation is determined with the angle $\varphi_{P R O J}$. The shapes of the cross-section of the cuts performed with conical picks have been modelled in a quite a simple manner so far. For example, in case of unrelieved cuts, they are triangular (Frenyo \& Lange, 1993; Haaf, 1992; Hekimoglu \& Fowell, 1991; Mahnert et al., 1988) - Fig. 5a. The side surfaces of the cut are inclined towards the perpendicular to the cut bottom under the angle corresponding to the breakout angle $\psi$, or - under the angle resulting from the projection of the conical pick onto the perpendicular plane towards the pick movement direction. The triangle height corresponds to the depth of the cut $g$. Relieved cuts (Fig. 5b) are modelled on the other hand in the form of a parallelogram with its sides inclined under the angle $\psi$. The length of the base of this parallelogram results from the values of the cutter spacing $t$, while its height equals the cut depth $g$. For larger depths, it is limited to $3 \mathrm{~cm}$ to limit the side edge length of the cut (Knissel \& Wiese, 1981; Wiese, 1982). Once this value is reached by sections representing side edges of the cut cross-section, it is assumed that the side surfaces are running parallel to the projection of the pick axis on the plane projection (Wiese, 1982).

The measurements made for the actual shape of cuts made with a conical pick have revealed that it largely depends on the geometry of the pick performing it and its position relative to the cut rock surface and cutting direction (Fig. 6). The shape of the side surfaces and bottom of the cut is, to a high degree, the consequence of indenting the pick into the cut rock. Self detachment of the cut material under an angle corresponding to the angle of side crushing takes place relatively close to a free surface. This is also confirmed by rock mining process investigations under- 
taken by other institutions - e.g. (Vorona, 2012). The real shapes of cuts being performed with conical picks are therefore considerably deviating from theoretical shapes used commonly. Cut geometry modelling should therefore be closely linked to the geometry of the picks performing such cuts.

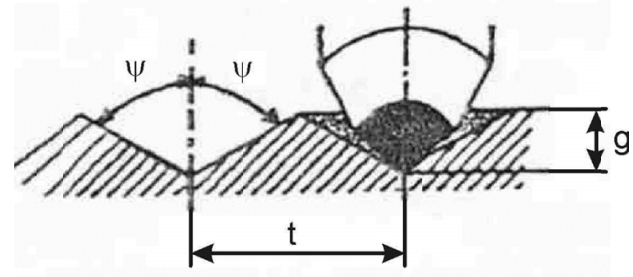

a)

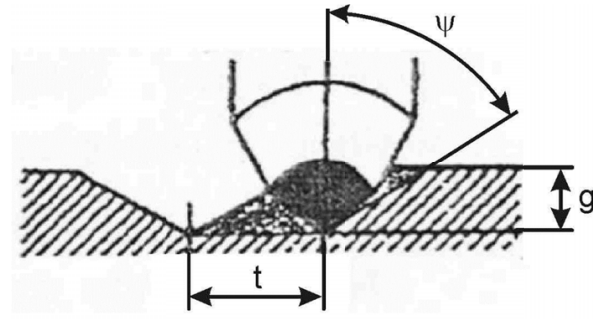

b)

Fig. 5. The models of cuts made with conical pick used so far (Mahnert et al., 1988):

a) unrelieved cut, b) relieved cut

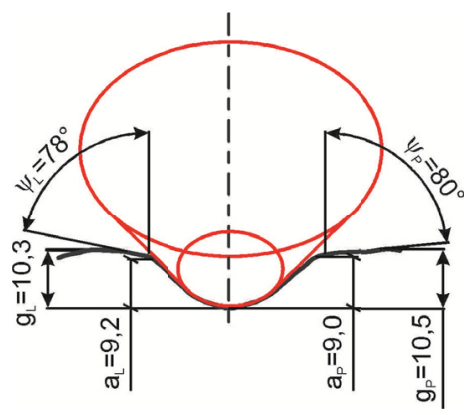

a)

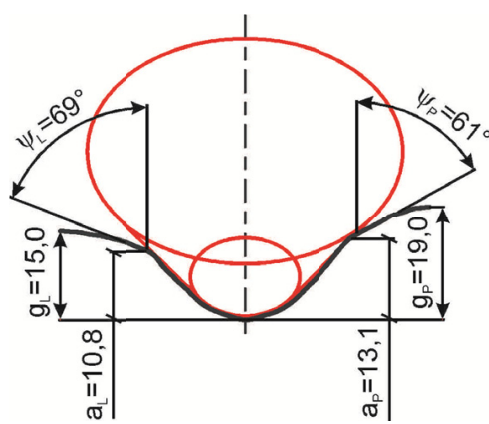

b)

Fig. 6. Actual shape of cross-section of cuts made with conical pick in concrete block for the assumed depth of cut (Cheluszka \& Dziędziel, 2015): a) $g_{Z}=10 \mathrm{~mm}$, b) $g_{Z}=20 \mathrm{~mm}$

In the case of conical picks, the tip and shank are shaped as a rotating solid, which can be presented as a combination of a certain number of solid elements in the form of cylinders and chamfered cones with the height $l_{O j}$ and base diameter $d_{O j}$ (Fig. 7). The pick vertex (point S) is an intersection point of the pick's longitudinal axis with the side surface of the ball with the radius $R_{O}$, being the end of the pick. Due to the spatial orientation of the pick in relation to the cutting direction (conditioned by the pick axis positioning angle value $\delta$, its deflection angle $\varepsilon$ and the angle describing the direction of the pick speed resultant vector $\rho$-Fig. 8), the pick vertex does not have to be this point of the pick which is closest towards the cut bottom (Cheluszka, 2015).

A model of cuts made with conical picks was established for the purpose of simulating the rock cutting process with cutting heads of a boom-type roadheader. The model is representing the actual geometry of cuts, which was determined during measurements carried out on a concrete block at a laboratory of the Institute of Mining Mechanisation, Faculty of Mining and Geology, Silesian University of Technology (Cheluszka \& Dziędziel, 2015). The cross-section of the cut 

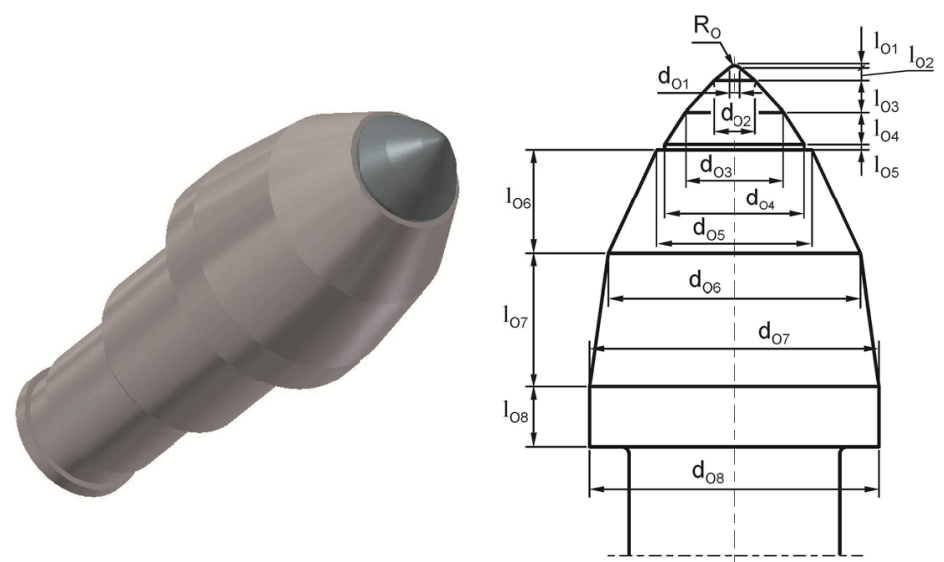

Fig. 7. Geometric model of conical pick working part

in the plane perpendicular to the cutting direction was modelled in the form of a polygon created with three plane figures (Fig. 9) (Cheluszka, 2015):

- pick working part projection onto a plane perpendicular to the pick movement direction;

- polygons with vertexes in the points: $\mathrm{E}, \mathrm{F}$ and $\mathrm{G}$ and $\mathrm{H}, \mathrm{K}$ and L representing the sections of rock layers subjected to self detachment within the limits of the side surfaces of cuts.

A projection envelope of the working part of the pick onto the plane perpendicular to the resultant vector of the pick vertex speed is determined in the first place (the plane of the cut cross-section). It is limited with a line created by arches of ellipses with their centres in the points $\mathrm{O}_{\mathrm{j}}$ and semi-axes $a_{j}$ and $b_{j}$ (for $j=1,2, \ldots, N_{S}$ ) and the sections: $\overline{\mathrm{A}_{\mathrm{j}} \mathrm{B}_{\mathrm{j}}}$ and $\overline{\mathrm{C}_{\mathrm{j}} \mathrm{D}_{\mathrm{j}}}$ of straights tangential to the ellipses. This area is intersected by a broken line representing a penetration

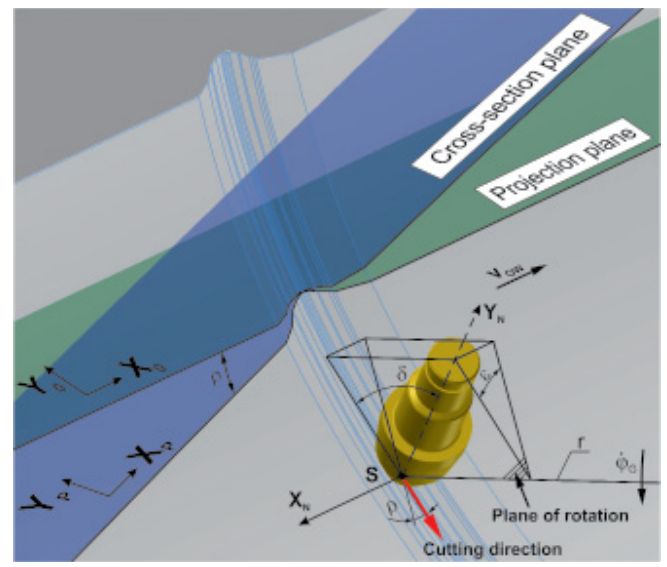

Fig. 8. Spatial orientation of pick relative to its advancement direction (cutting direction) and to the surface of the cut rock

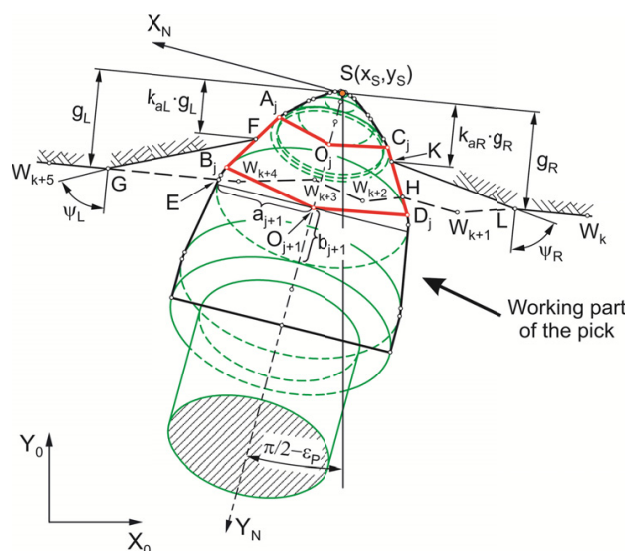

Fig. 9. New model of cut made with conical pick 
edge of the considered plane by a free surface of rock in the place in which a given pick is performing a cut. This line intersects the pick working part projection envelop in the points: $\mathrm{E}$ and $\mathrm{H}$. Their position is determining a value by which the pick is deepened in the surface of the worked rock.

The coordinate values of central points and the length of ellipse semi-axis being a projection of bases of elementary solids of revolutions consisting of a working pick part on the plane perpendicular to the advancement direction of the pick movement, are described by the following values:

$$
\begin{aligned}
& a_{j}= \begin{cases}R_{O}, & \text { when } j=0 \\
0,5 \cdot d_{O j}, & \text { when } j>0\end{cases} \\
& b_{j}= \begin{cases}R_{O}, & \text { when } j=0 \\
a_{j} \cdot \cos \delta \cdot \cos (\varepsilon-\rho), & \text { when } j>0\end{cases} \\
& x_{O j}= \begin{cases}R_{O} \cdot \cos \delta \cdot \sin (\varepsilon-\rho), & \text { when } j=0 \\
l_{O j} \cdot \cos \delta \cdot \sin (\varepsilon-\rho), & \text { when } j=1 \\
x_{O j-1}+l_{O j} \cdot \cos \delta \cdot \sin (\varepsilon-\rho), & \text { when } j>1\end{cases} \\
& y_{O j}= \begin{cases}R_{O} \cdot \sin \delta, & \text { when } j=0 \\
l_{O j} \cdot \sin \delta, & \text { when } j=1 \\
y_{O j-1}+l_{O j} \cdot \sin \delta, & \text { when } j>1\end{cases}
\end{aligned}
$$

whereas the coordinates of the centres of the considered ellipses in the local system connected with the pick $\mathrm{X}_{\mathrm{N}} \mathrm{Y}_{\mathrm{N}}$ (Fig. 9) assumes the following form:

$$
\left\{\begin{array}{l}
x_{O j}^{N}=0 \\
y_{O j}^{N}=\sqrt{x_{O j}^{2}+y_{O j}^{2}}
\end{array}\right.
$$

When considering further the coordinate system connected with a given pick $\left(\mathrm{X}_{\mathrm{N}} \mathrm{Y}_{\mathrm{N}}\right)$, then the position of end points of the sections $\overline{\mathrm{A}_{\mathrm{j}} \mathrm{B}_{\mathrm{j}}}$ - being a projection of the considered constituting solids of revolutions of which the working part of the pick consists of - on the plane of the cut cross-section, is determined from the following dependencies:

$$
\left\{\begin{array}{l}
x_{A j}^{N}=\frac{a_{j}^{2} \cdot b_{j+1} \cdot x_{B j}^{N}}{\sqrt{a_{j}^{2} \cdot b_{j+1}^{2} \cdot\left(x_{B j}^{N}\right)^{2}+a_{j+1}^{2} \cdot b_{j}^{2} \cdot\left[a_{j+1}^{2}-\left(x_{B j}^{2}\right)^{2}\right]}} \\
y_{O j}^{N} \cdot \sqrt{a_{j}^{2} \cdot b_{j+1}^{2} \cdot\left[b_{j+1}^{2}-\left(y_{B j}^{N}-y_{O j+1}^{N}\right)^{2}\right]+a_{j+1}^{2} \cdot b_{j}^{2} \cdot\left(y_{B j}^{N}-y_{O j+1}^{N}\right)^{2}}+ \\
y_{A j}^{N}=\frac{+a_{j+1} \cdot b_{j}^{2} \cdot\left(y_{B j}^{N}-y_{O j+1}^{N}\right)}{\sqrt{a_{j}^{2} \cdot b_{j+1}^{2} \cdot\left[b_{j+1}^{2}-\left(y_{B j}^{N}-y_{O j+1}^{N}\right)^{2}\right]+a_{j+1}^{2} \cdot b_{j}^{2} \cdot\left(y_{B j}^{N}-y_{O j+1}^{N}\right)^{2}}}
\end{array}\right.
$$


The coordinate $y_{B j}^{N}$ values are determined iteratively in the function of the coordinate $x_{B j}^{N}$ in such a manner that its value calculated from the equation of the straight $A_{j} B_{j}$ :

$$
y_{B j}^{N}=y_{A j}^{N}+\frac{b_{j+1} \cdot x_{B j}^{N} \cdot\left(x_{B j}^{N}-x_{A j}^{N}\right)}{a_{j+1} \cdot \sqrt{a_{j+1}^{2}-\left(x_{B j}^{N}\right)^{2}}}
$$

is compared to the value determined from the equation of an ellipse with its centre in the point $O_{j+1}$ :

$$
y_{B j}^{N}=y_{O j+1}^{N}-b_{j+1} \cdot \sqrt{1-\left(\frac{x_{B j}^{N}}{a_{j+1}}\right)^{2}}
$$

The coordinate values $x_{A j}^{N}$ and $y_{A j}^{N}$ in the formula (10) are calculated here using the expression (9). The point $\mathrm{B}_{\mathrm{j}}$ coordinates are searched for a variability range of the coordinate value $x_{B j}^{N}$ in the range of zero to $a_{j+1}$.

Analogously, as for the points $A_{j}$ and $B_{j}$, values are determined for the coordinates of the points $C_{j}$ and $D_{j}$. The procedure described is used with reference to all elementary solids making up the working part of the pick performing a cut whose shape is modelled in a cross-section plane. An outline of the cut cross-section, resulting directly from the shape of the pick performing it, is determined this way.

The cross-section plane of each cut is deflected from projection planes by the angle $\rho_{i}$ defining a temporary direction of the pick movement speed resultant vector (for $i=1, \ldots, N$ ) - Fig. 8 . The value of this angle results from a combination of the peripheral speed vector of the given pick vertex in rotary motion around the axis of rotation of the cutting head $\left(\dot{\varphi}_{G} \cdot r_{i}\right)$ and from the peripheral speed vector of cutting heads' advancement in working movement $\left(v_{o w}\right)$ :

$$
\rho_{i}=\operatorname{arctg}\left(\frac{v_{o w}}{\dot{\varphi}_{G} \cdot r_{i}}\right)
$$

By going first to the coordinates system connected with the plane of the cut cross-section $\left(\mathrm{X}_{\mathrm{P}} \mathrm{Y}_{\mathrm{P}}\right)$, and then by performing transformation of the coordinates of characteristic points of the pick contour to the system of coordinates connected with the projection plane $\left(\mathrm{X}_{0} \mathrm{Y}_{0}\right)$, dependencies are attained connecting the coordinates of such points in the pick coordinate system $X_{N} Y_{N}$ and in the coordinate system of the projection plane $\mathrm{X}_{0} \mathrm{Y}_{0}$ :

$$
\left\{\begin{array}{l}
x_{A j}=x_{S i}-\frac{\left[x_{A j}^{N} \cdot \cos \left(\frac{1}{2} \pi-\varepsilon_{P}\right)+y_{A j}^{N} \cdot \sin \left(\frac{1}{2} \pi-\varepsilon_{P}\right)\right]}{\cos \rho_{i}} \\
y_{A j}=y_{S i}-\left[-x_{A j}^{N} \cdot \sin \left(\frac{1}{2} \pi-\varepsilon_{P}\right)+y_{A j}^{N} \cdot \cos \left(\frac{1}{2} \pi-\varepsilon_{P}\right)\right]
\end{array}\right.
$$

for $j=1,2, \ldots, N_{S}$, 
whereas the angle of pick axis projection deflection relative to the axis $\mathrm{X}_{0}$ :

$$
\varepsilon_{P}=\operatorname{arctg}\left(\frac{\operatorname{tg} \delta_{i}}{\sin \varepsilon_{i}}\right)
$$

and

$$
\left\{\begin{array}{l}
x_{S i}=l_{i}^{T}+v_{\text {ow }} \cdot \frac{\vartheta_{i}}{\dot{\varphi}_{G}} \\
y_{S i}=r_{i}^{T}
\end{array}\right.
$$

where:

$x_{S i}, y_{S i}$ - coordinates of the vertex penetration point of the $i$-th pick (point $\mathrm{S}$ ) of the considered projection plane,

$\delta_{i}, \varepsilon_{i}-$ respectively: pick positioning angle and axis deflection angle of the $i$-th pick (cf. Fig. 8), $r_{i}^{T}, l_{i}^{T}, \vartheta_{i}-$ coordinates of the vertex of the $i$-th pick after transformation,

$N_{S}$ - the number of elementary solids separated from the working part of the pick.

The position of side surfaces of the cut in the part in which self detachment of the rock occurs, is conditioned by the position of the edge: $\overline{\mathrm{FG}}$ and $\overline{\mathrm{KL}}$ (Fig. 9). The self detachment effect originates from properties of the worked rock characterised by the breakout angle $\psi$. A starting point for determining the position of ends of the above-mentioned sections is determination of cut depth. The distance of the points $\mathrm{E}$ and $\mathrm{H}$ from the cut bottom measured in the direction perpendicular to the free surface of rock are understood here as cut depth. Separate cut depths on the left and right side of the cut (respectively for values $g_{L}$ and $g_{R}$ ) are determined for the purpose of determination of coordinates of the points $\mathrm{F}$ and $\mathrm{K}$. The distance for these points situated on the pick envelop, measured from the cut bottom, are proportional to cut depth and result from factors of the pick impact range: $k_{a L}\left(g_{L}\right)$ and $k_{a R}\left(g_{R}\right)$. The factors are defined as a ratio of distance from the cut bottom of the place from which the side surface of the cut is inclined under the angle $\psi$ to cut depth (Cheluszka \& Dziędziel, 2015).

The coordinate values of points $\mathrm{G}$ and $\mathrm{L}$ in the cross-section plane of the cut are obtained as a result of intersection of the straights going through, respectively, points: $\mathrm{F}$ and $\mathrm{K}$ and inclined towards the perpendicular to the cut bottom under the angle: $\psi_{L}$ and $\psi_{R}$ with a broken line being a penetration edge of the projection plane by the free surface of rock. For example, the G point coordinates are described as follows:

$$
\left\{\begin{array}{l}
x_{G}=\frac{x_{F} \cdot \operatorname{tg} \lambda-x_{W k} \cdot \operatorname{tg} \beta-y_{F}+y_{W k}}{\operatorname{tg} \lambda-\operatorname{gg} \beta} \\
y_{G}=\operatorname{tg} \lambda \cdot\left(x_{G}-x_{F}\right)+y_{F}
\end{array}\right.
$$

whereas auxiliary angles:

$$
\begin{aligned}
& \lambda=\pi+\alpha_{M}-\psi_{L} \\
& \beta=\operatorname{arctg}\left(\frac{y_{W k+1}-y_{W k}}{x_{W k+1}-x_{W k}}\right)
\end{aligned}
$$


where:

$x_{W k}, y_{W k}-$ vertex coordinates of broken line forming a breakout line in the considered section plane of the cut $\left(k=1, \ldots, N_{W}\right)$,

$N_{W}$ - the number of breakout points in the analysed projection plane,

$\alpha_{M}$ - the angle determining the measurement direction of cut depth measured from the axis $\mathrm{X}_{0}$ of the coordinate system $\mathrm{X}_{0} \mathrm{Y}_{0}$,

$\psi_{L}-$ the breakout angle conditioning section $\overline{\mathrm{FG}}$ deviation of the cut outline from the measurement direction of cut depth.

\section{Computer simulation of cutting process}

The algorithm of generating a projection of cuts made with conical picks presented above was achieved practically in the Embarcadero RAD Studio environment. An established algorithm of a cutting process simulation procedure with a transverse cutting head of a boom-type roadheader was implemented in the computer programme created. The generation of cut shapes in particular projection planes was based on the use of graphical objects (regions) and functions dedicated to support them (in particular: CreateRectRgn and CombineRgn) enabling to perform such operations as: creating, adding and subtracting of regions. Access to such resources from the level of the Embarcadero RAD Studio programming environment is possible via a WINAPI interface. Regions are created by generating a closed broken line with the set nodes forming a periphery of an area confined by the line. The location of individual border line nodes is conditioned by coordinate values of characteristics points of the breakout in a flat coordinate system of a projection plane $\left(\mathrm{X}_{0} \mathrm{Y}_{0}\right)$.

Four representation regions are considered for each cut made by a pick taking part in the rock mining process (Fig. 10):

1) rock solid section (breakout) in the direct surrounding of the cutting head - the area is designated as $\mathfrak{R}_{\mathbf{R}}($ ),

2) a projection on the projection plane of the pick's working part whose vertex intersects this plane in the point $\mathrm{S}\left(x_{S i}, y_{S i}\right)$ - this region is designated as $\mathfrak{R}_{\mathrm{T}}()$,

3) side crushing of the rock on the left and right side of the rock - the areas are designated, respectively, as: $\mathfrak{R}_{\mathrm{SCL}}(\mathrm{)})$ and $\mathfrak{R}_{\mathrm{SCR}}(\mathrm{)}$.

The region $\mathfrak{R}_{\mathrm{T}}(\mathrm{S}, \mathrm{A}, \mathrm{B}, \mathrm{C}, \mathrm{D})$ is created in the first place after determining the pick outline shape for its set position and after determining the $S$ point coordinates in the considered projection plane. As a result subtracting of the region $\mathfrak{R}_{\mathrm{T}}(\mathrm{S}, \mathrm{A}, \mathrm{B}, \mathrm{C}, \mathrm{D})$ from the region $\mathfrak{R}_{\mathbf{R}}(\mathrm{W})($ CombineRgn function is called with the parameter RGN_DIFF), a new breakout shape is obtained in the impact area of the considered pick with exclusion of the effect of side crushing of rock. The arguments of the function creating a given region (CreateRectRgn) are nodal points of the broken line confining the considered area. In case of a breakout (of region $\mathfrak{R}_{\mathbf{R}}$ ), the periphery is created based on the nodal points: $\mathrm{W}\left(x_{W 1}, y_{W 1}\right) \div \mathrm{W}\left(x_{W N W}, y_{W N W}\right)$. On the other hand, the region $\mathfrak{R}_{\mathbf{T}}$ is confined with a broken line created by the points A, B, C and D of the pick working part envelope (cf. Fig. 9). The position of such envelop on the projection plane results from the position of point $\mathrm{S}$. At this stage, the position of the point $\mathrm{E}$ and $\mathrm{H}$ is determined as intersection points of the pick outline with a breakout periphery.

The coordinate values of characteristic points of areas modelling side rock detachment on the both sides of the pick are determined in the next stage of cut shape generation (points: F, G, K 
and L). By knowing the position of the points, it is possible to generate two regions representing the side rock crushing effect after pick transition: $\mathfrak{R}_{\mathbf{S C L}}(\mathrm{E}, \mathrm{F}, \mathrm{G}, \mathrm{W})$ and $\mathfrak{R}_{\mathbf{S C R}}(\mathrm{H}, \mathrm{K}, \mathrm{L}, \mathrm{W})$. Apart from coordinates of characteristic points of the side detachment zone, in the pool of arguments for a function generating such regions there are also coordinates of nodal points of the breakout $\mathrm{W}$ border line between points $\mathrm{E}$ and $\mathrm{G}$ as well as $\mathrm{H}$ and $\mathrm{L}$.

By performing again a subtracting operation: $\mathfrak{R}_{\mathbf{R}}-\mathfrak{R}_{\mathbf{S C L}}$ and $\mathfrak{R}_{\mathbf{R}}-\mathfrak{R}_{\mathbf{S C R}}$, a region modifying the rock solid will be modified and the breakout shape in the given projection plane will be updated. The above procedure is repeated for all the picks taking part in heading face surface cutting for the set values of web and height of the cut layer in the considered projection plane.

Figure 11 compares the projections of cuts made with picks of a transverse cutting head generated using the existing model (a) and the new model presented in this paper (b). In both
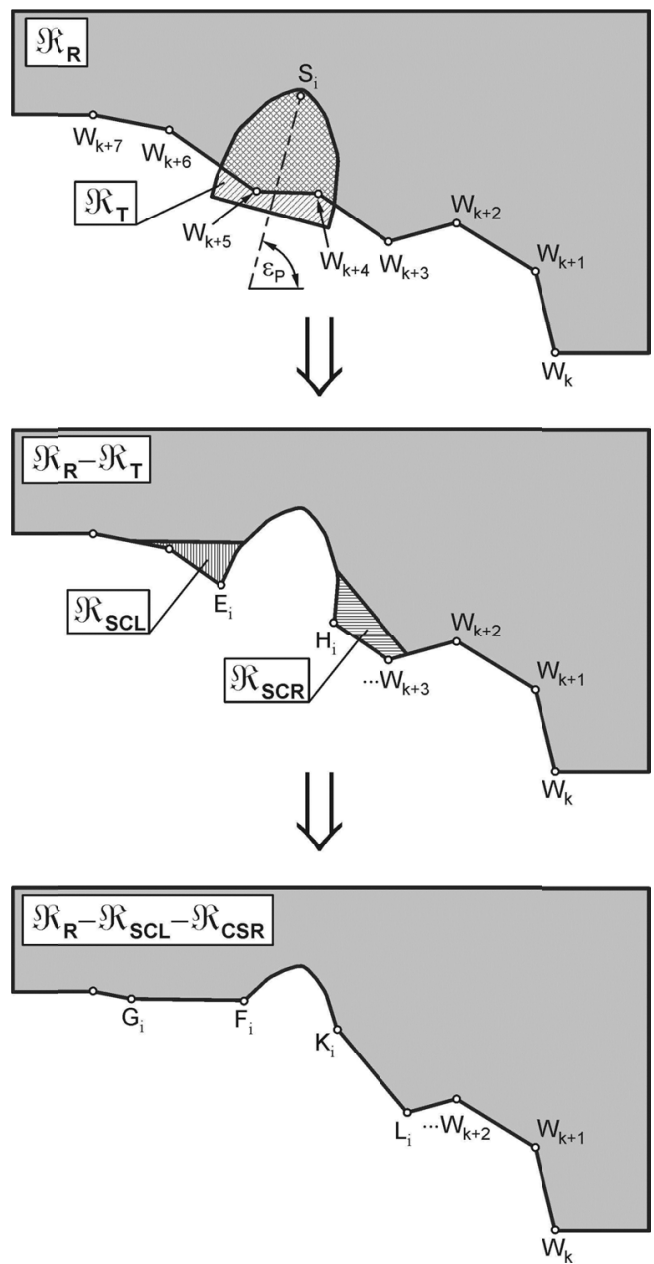

Fig. 10. Generation method of cut shape during computer simulation of cutting process

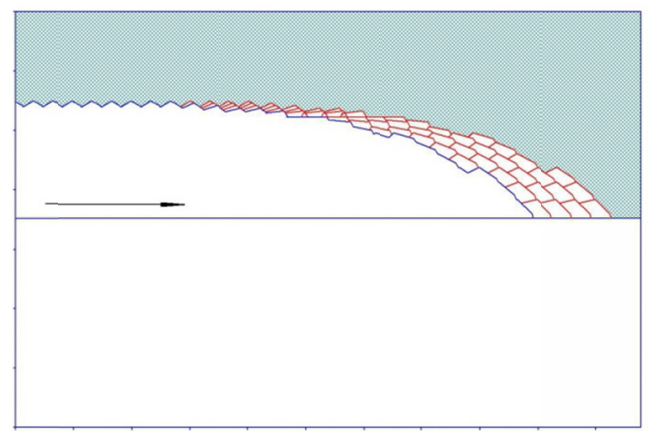

a)

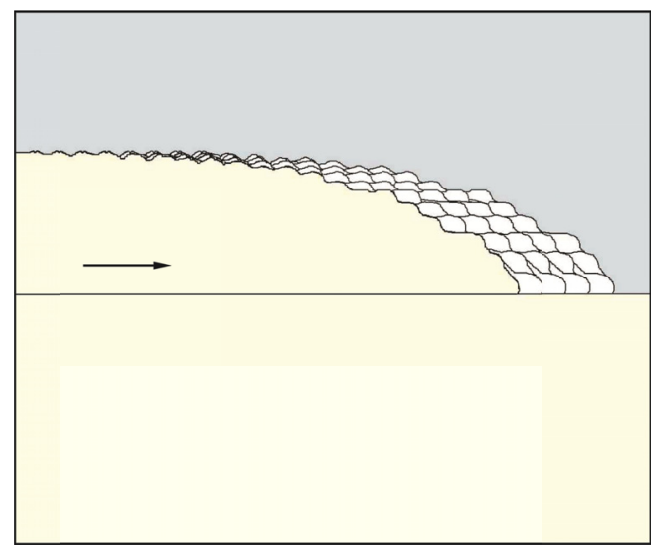

b)

Fig. 11. Comparison of cut projections made during one rotation of cutting head equipped with 80 conical picks in the projection plane for $\varphi_{P R O J}=90^{\circ}$ :

a) model used to date, b) new model (computer simulation performed for: $z=0.2 \mathrm{~m}$; $h=0.847 \mathrm{~m} ; \dot{\varphi}_{G}=4.2 \mathrm{rad} / \mathrm{s} ; v_{o w}=0.1 \mathrm{~m} / \mathrm{s}$ ) 
cases, a projection was made in a plane determined by the boom longitudinal axis $\left(\varphi_{P R O J}=90^{\circ}\right)$. Clear differences in the shape of individual cuts are visible, especially for picks located in the frontal part of the head (pick vertexes situated relatively close to the cutting head axis of rotation). Side rock detachment is clearly visible in the case of cuts performed by picks arranged on small radii. Due to the sequence of picks entering the worked solid, side detachment may by asymmetric and be more accentuated on one side of the cut. The cuts generated using the existing model have their shapes similar to parallelograms, which results from the assumed triangular shape of their cross section. Due to the new method of cut modelling, their shape is very similar to the pick contour, which is reflected in reality as shown by measurements. The depth of cuts in the projection plane considered here, generated from a computer simulation based on the new modelling method, are smaller compared to the values obtained using a model used so far for all the picks taking part in the rock cutting process (Fig. 12 - the bars in green). A ratio of cut depth for a new model (NEW) and the model used to date (OLD), is within the limits of 0.28 to 0.97. In most of the cases, i.e. for $80 \%$ of picks, it spans between 0.5 and 0.8 (Fig. 13a). A ratio between the field area of the cross section of cuts accomplished using the newly developed model (NEW) and the values achieved using the model used to date (OLD), assumes the values of 0.5 to even 2.9 (Fig. 12 - bars in blue). The field area of cross section of the cuts generated using the developed model exceeded, for over a half of the picks taking part in the cutting process, the values obtained using the existing model by even $20 \%$ (Fig. 13b). The highest growth in values of the cross section field was recorded for picks arranged on large radii close to the maximum value (it relates notably to picks number 41 to 44,55 and 56).

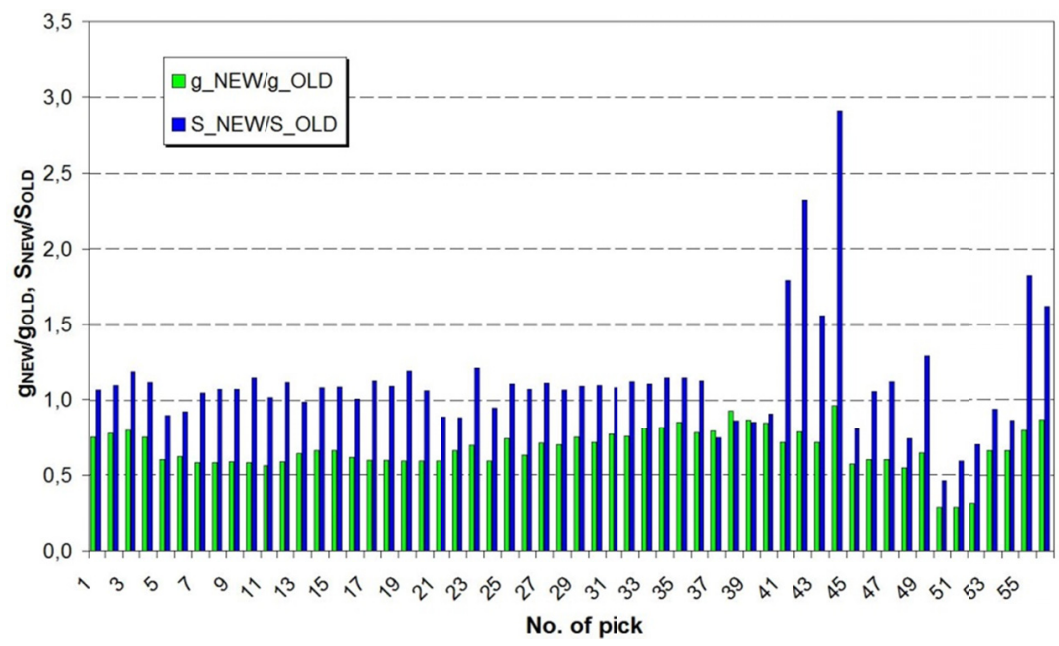

Fig. 12. Comparison of depth and field area of cross-section of cuts made with picks of the studied cutting heads obtained based on cut projections $\left(\varphi_{P R O J}=90^{\circ}\right)$ using the existing model (OLD) and the new model (NEW)

Cut depth is varying as picks are being displaced within the cutting zone limits during a computer simulation of a cutting process using a newly developed model (Fig. 14). This phenomenon had not been considered in the models of the process applied earlier. The depth of cuts is increased 


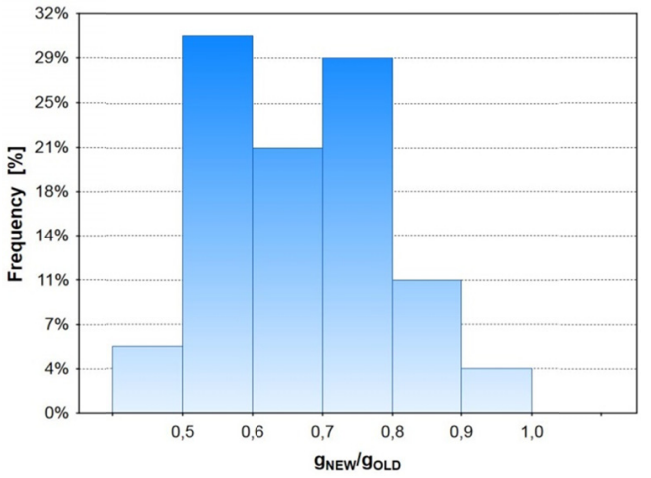

a)

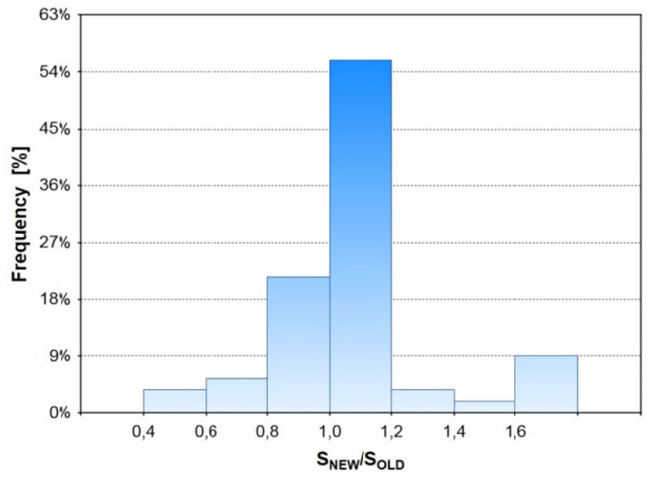

b)

Fig. 13. Histograms of ratios for cut depth (a) and field areas of cross-sections of cuts (b) for $\varphi_{P R O J}=90^{\circ}$ obtained using the existing model (OLD) and the new model (NEW)

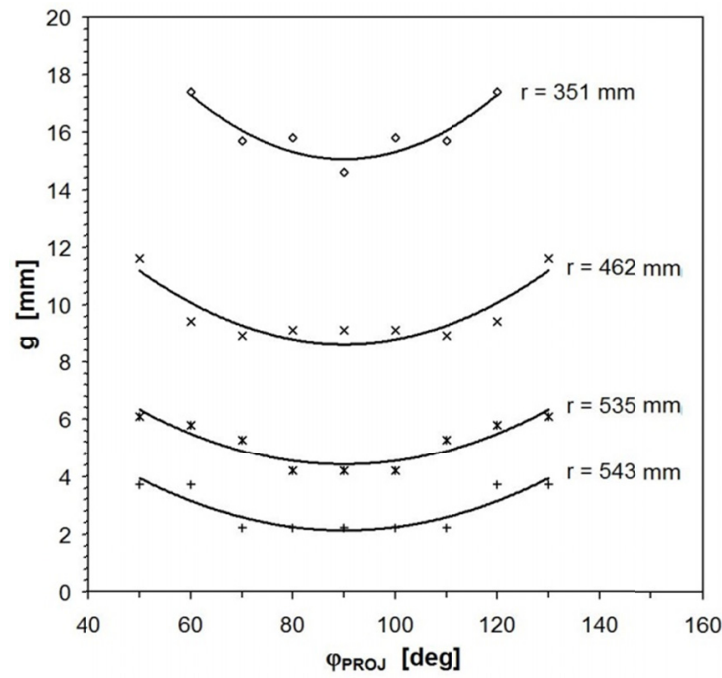

Fig. 14. Curve of variations in the depth of cuts made by selected picks during cutting head rotation

the further we go away from the plane determined by the axis of rotation of the cutting head and the longitudinal axis of the boom $\left(\varphi_{P R O J}=90^{\circ}\right)$. For example, for a pick whose vertex is situated in the distance $r=351 \mathrm{~mm}$, the depth of the cut made by the pick within the entire variability range of the angle $\varphi_{P R O J}$, is changing within the range of 14.6 to $17.4 \mathrm{~mm}$, hence by $20 \%$. However, for a pick whose vertex is situated in the distance $r=543 \mathrm{~mm}$, the cut depth variability range was even higher and was over $68 \%$. Considering that, according to the Evans formula, a pick load is directly proportional to the square of cut depth, it means that, when performing a cutting process by the mentioned pick, the average value of cutting force changes almost 3-fold.

Variations in the depth of cuts carried out by particular cutting head picks, as they are advancing along the surface of the cut rock, are influencing the size and load character of the cutting 
head (Fig. 15). The average value of the curve of the moment of load forces on the cutting head shaft $M_{O B}$ achieved for its one revolution using a newly developed model ( $\left.22 \mathrm{kNm}\right)$ is higher by $10 \%$ against the average value of this load achieved from a computer simulation based on the existing model. Average cutting power $\left(N_{U}=110 \mathrm{~kW}\right)$ and average energy consumption of the process $\left(E_{j}=2.9 \mathrm{kWh} / \mathrm{m}^{3}\right)$ is of similar proportions. A variability range of the cutting head load (Fig. 15b) is clearly higher, however, as compared to variations of this load achieved using a model used to date (Fig. 15a). An amplitude of the moment of load forces obtained from a computer simulation based on the new cutting process model is larger by $75 \%$ as compared to

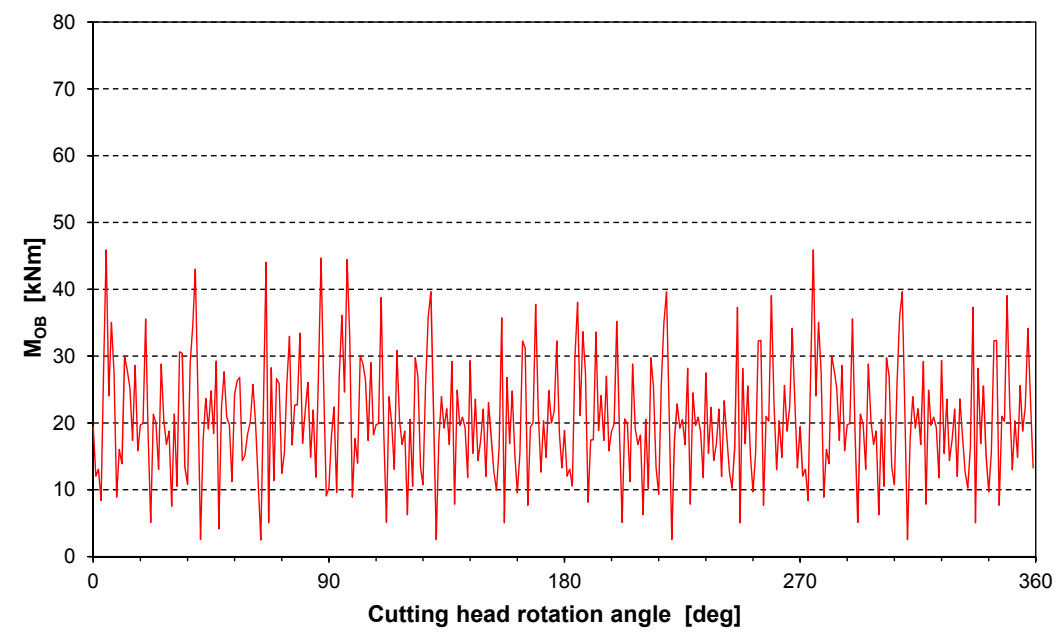

a)

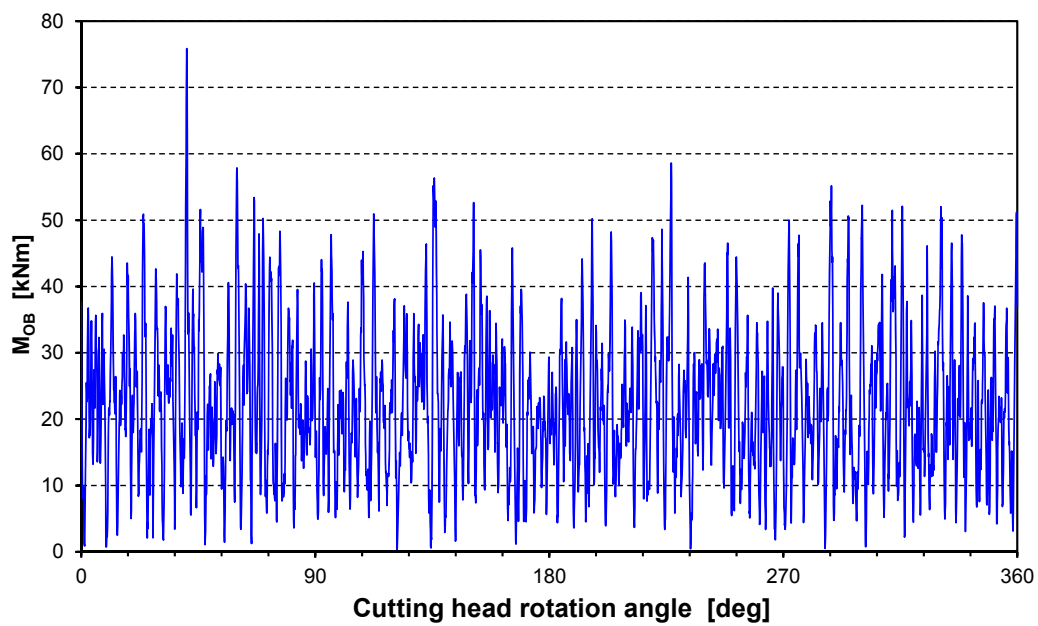

b)

Fig. 15. The curve of the moment of load forces on the cutting head shaft in the function of cutting head rotation angle: a) model used to date, $b$ ) new model (computer simulation performed for: $\left.z=0.2 \mathrm{~m} ; h=0.847 \mathrm{~m} ; \dot{\varphi}_{G}=4.2 \mathrm{rad} / \mathrm{s} ; v_{o w}=0.1 \mathrm{~m} / \mathrm{s} ; R_{c}=80 \mathrm{MPa}\right)$ 
its curve load value obtained from a computer simulation based on the existing cutting process model. Variations in the depth of cuts occurring for rock cutting by picks situated in the cutting zone is a source of a higher cutting head load and of an additional vibration component of the load.

\section{Summary}

A computer simulation of the mining process enables to determine the progress of vibrations excitation in a cutting system and other roadheader assemblies connected with the cutting system. This constitutes a basis for analysing the dynamics of this kind of machines when they are performing a working process. Hence a mathematical description of the process should reflect, as far as possible, the actual progress. A complex character of the cutting process carried out by mining cutting machines resulting from rock cutting mechanics, pick kinematics and a stochastic character of multiple factors significantly influencing its progress (including parameters characterising the properties of the cut medium resulting from a geological rock mass structure within a heading face of the drilled heading) makes it impossible to represent it in a realistic fashion. For this reason, a number of simplifying assumptions is used at the modelling stage.

Experimentally verified model of the mining process with boom-type roadheader transverse heads presented in this article, in scope of the modelling method of the progress of cuts made by particular picks, their shape and identification of values of geometrical parameters of cuts as picks are being advanced, is an important step in solving this issue. By modelling the actual shape of cuts made by conical picks with a currently used geometry and also by considering variability in the depth of cuts resulting from the actual kinematics of transverse heads and the actual shape of the heading face surface, it should contribute to making the results of numerical calculations more realistic.

The computer simulations performed using a newly developed mathematical model indicate the significant impact of the considered factors on the size and character of loading the cutting heads accompanying cutting. This will be reflected by the size and character of dynamic loads of the cutting heads drive and other boom-type roadheader components obtained in computer simulations. This should contribute to achieving more credible representation of roadheader dynamics when performing the cutting process.

\section{Acknowledgements}

The work has been implemented under the research project titled "Control of roadheader cutting heads movement for reduction of energy consumption of mining and dynamic loads" co-financed by the National Centre for Research and Development under the Applied Research Projects (agreement no. PBS3/B2/15/2015).

\section{References}

Cheluszka P., 2012. Metrologia organów roboczych górniczych maszyn urabiających. Wydawnictwo Politechniki Śląskiej, Gliwice.

Cheluszka P., 2015. Modeling of the geometry of cuts for purpose of the computer simulation of a point-attack picks cutting process. $34^{\text {th }}$ International Conference "Technical diagnostics of machines and manufacturing equipment DIAGO 2015", 66-74. 
Cheluszka P., Dziędziel J., 2015. Identyfikacja cech geometrycznych skrawów wykonanych nożami kombajnów górniczych $z$ wykorzystaniem skanera laserowego. Przegląd Górniczy 71, 4, 72-82.

Dolipski M., Cheluszka P., 1999, Dynamic model of a roadheader's cutting system which incorporates transverse cutter heads. Arch. Min. Sci. 44, 1, 113-146.

Dolipski M., Cheluszka P., 1998. Bestimmung der Form des Schnittkraftverlaufs an Kegelmeißeln von Vortriebsmaschinen. Glückauf-Forschungshefte 59, 4, 123-127.

Dolipski M., Jaszczuk M., Cheluszka P., Sobota P., 2001. Mathematical modelling of the roadheader's cutting process. $17^{\text {th }}$ International Mining Congress and Exhibition of Turkey - IMCET 2001, 645-652.

Evans I., 1984. Basic mechanics of the point-attack pick. Colliery Guardian, May, 189-193.

Frenyo P., Lange W., 1993. Die Auslegung von Schneidköpfen für optimale Löseleistungen. Glückauf 129, 7, 524-531.

Haaf J., 1992. Das Verschleiß- und Drehverhalten von Meißeln für Teilschnitt-Vortriebsmaschinen. Diss. TU Clausthal.

Hekimoglu O.Z., Fowell R.J., 1991. Theoretical and practical aspects of circumferential pick spacing on boom tunnelling machine cutting heads. Mining Science and Technology 13, 3, 257-270.

Huang H., Lecampion B., Detournay E., 2013. Discrete element modeling of tool-rock interaction I: Rock cutting. Int. Journal for Numerical and Analytical Methods in Geomechanicsm 37, 1913-1929.

Hurt K.G., Evans I., 1981. Point attack tools: an evaluation of function and use for rock cutting. Mining Engineer 140, 234, 673-675.

Jaime M.C., Gamwo I.K., Lyons, D.K. Lin J.S., 2010. Finite Element Modeling of Rock Cutting. $44^{\text {th }}$ U.S. Rock Mechanics Symposium and $5^{\text {th }}$ U.S.-Canada Rock Mechanics Symposium, 1085-1092.

Jamie M.C., 2011. Numerical modeling of rock cutting and its associated fragmentation process using the finite element method. Diss. University of Pittsburgh.

Knissel W., Mertens V., Kleinert H.-W., Mittmann M., 1984. Verfahren zur Auslegung und Optimierung der Schneidköpfe von Teilschnitt-Vortriebsmaschinen. Glückauf 120, 23, 1534-1539.

Knissel W., Wiese F., 1981. Möglichkeiten zur Verbesserung des Lösevorgangs von Teilschnitt-Vortriebsmaschinen. Glückauf 117, 20, 1360-1366.

Kui-Dong G., Chang-Long D., Song-Yong L., 2012. An empirical mathematic model of drums cutting torque. Journal of Theoretical and Applied Information Technology 46, 2, 785-789.

Mahnert U., Gerhardt H., Bellmann A., 1988. Untersuchungen zur Gesteinszerspannung mit Rundschaftmeißeln im Hinblick auf die rechnergestützte Meißelbestückung und dimensionierung von Teilschnittgewinnungsorganen. Neue Bergbautechnik 18, 10, 375-381.

Mahnert U., Gerhardt H., Bellmann A., 1990. Rechnergestützte Optimierung der Arbeitsweise von Schneidköpfen an Teilschnitt-Vortriebsmaschinen. Glückauf-Forschungshefte 51, 6, 277-282.

Rojek J., Labra C., Oñate E., 2010. Discrete element simulation of rock cutting processes. $10^{\text {th }}$ International Conference "Modern building materials, structures and techniques", 1040-1044.

Rostami J., Ozdemir L., Neil D., 1994. Roadheaders performance optimization for miting and civil construction. $13^{\text {th }}$ Annual Technical Conference, Institute of Shaft Drilling Technology, 1-17.

Shenghua Y., 2004. Simulation of rock cutting by the finite element method. International ANSYS conference proceedings, 61-71.

Sobota P., 2015. The impact of the roadheader boom settings and pics position on the cutting depth. $34^{\text {th }}$ International Conference "Technical diagnostics of machines and manufacturing equipment DIAGO 2015", 249-257.

Tiryaki B., Ayhan M., Hekimoglu O.Z., 2001. A new computer program for cutting head design of roadheaders and drum shearers. $17^{\text {th }}$ International Mining Congress and Exhibition of Turkey - IMCET 2001, 655-662.

Vorona M., 2012. Optimierung des Schneidprozesses und Prognose der relevanten Arbeitsgrößen bei der Gesteinszerstörung unter Berücksichtigung des Meißelverschleißes. Diss. TU Bergakademie Freiberg.

Wiese H.-F., 1982. Grundlagenuntersuchung zur Optimierung der Lösearbeit von Teilschnitt-Vortirebsmaschinen mit Querschneidkop. Diss. TU Clausthal.

Xiang Ping Tang, Duan Yi Wang, 2014. Predication of rock cutting force of conical pick base on RBF Neural Network. Aplied Mechanics and Materials, 501-504, 92-95.

Xueyi Li, Binbing Huang, Chaochao Li, Shoubo Jiang, 2012. Dynamics Analysis on Roadheader Cutting Head Based on LS-DYNA. Journal of Convergence Information Technology 7, 23, 333-340. 